\title{
Occurrence of arbuscular mycorrhizal fungi in high altitude sites of the Patagonian Altoandina region in Nahuel Huapi National Park [Argentina]
}

\author{
María Silvana Velázquez ${ }^{1 \star}$, Sidney Luiz Stürmer ${ }^{2}$, Clara Bruzone ${ }^{3}$, Sonia Fontenla ${ }^{3}$, Marcelo Barrera ${ }^{4}$ \\ and Marta Cabello ${ }^{1}$
}

Received: June 22, 2016

Accepted: September 3, 2016

\begin{abstract}
Knowledge of the occurrence and diversity of arbuscular mycorrhizal fungi (AMF) in National Parks is essential for the establishment of policies for conservation. The aim of this study was to characterize the AMF communities in the Patagonian Altoandina region in Nahuel Huapi National Park, Argentina. We surveyed AMF spores associated with the rhizospheres of 9 plant species in the Patagonian Steppe (PS), Challhuaco Hill (ChH), Catedral Hill (CH), and Tronador Hill (TH) regions and detected a total of 27 Glomeromycota species. Acaulospora laevis was dominant at all sites. The AMF community was dominated by Acaulosporaceae, as regards the number of species and contribution of each one to the total number of spores. Three Glomeromycota families were detected at PS, the site with the lowest elevation; whereas five to six families were detected at $\mathrm{ChH}, \mathrm{CH}$, and $\mathrm{TH}$. Cluster analysis indicated that the AMF communities were grouped according to habitat. We concluded that certain patterns of the AMFcommunity structure detected were equivalent to those of high-altitude environments from other studies, while others were unique to the Patagonian region; thus suggesting that historical influences like dispersion and speciation played a critical role in shaping AMF community composition in such high-altitude environments.
\end{abstract}

Keywords: Acaulosporaceae, altitudinal gradient, Glomeromycota, species diversity, spore numbers, steppe

\section{Introduction}

High-mountain ecosystems extend above the upper limit of the timberline and exhibit many features of great ecologic value worldwide: Constituting one-fifth of the land area of the planet; such elevated regions represent one of the main sources of fresh water, serve as refuge for various animals and plants that are not found at lower altitudes, exhibit a wide biologic diversity because of substantial environmental variability; and are generally not modified by anthropic interference (Ferreyra et al. 2006). This last feature feature gives those elevated landscapes a sacrosanct status in this day and age. Owing to the harsh living conditions in high mountain environments, the resident biota of such regions display adaptive strategies that are of special interest from the biologic, ecologic, and biogeographic points of view (Körner 1999). High-mountain ecosystems - typically

\footnotetext{
${ }^{1}$ Instituto de Botánica Spegazzini, Universidade Nacional de La Plata, 53 \# 477 (1900), La Plata, Buenos Aires, Argentina

2 Departamento de Ciências Naturais, Universidade Regional de Blumenau, R. Antonio da Veiga, 140, 89030-903, Blumenau, SC, Brazil

${ }^{3}$ Laboratorio de Microbiología Aplicada y Biotecnología, Centro Regional Universitario Bariloche, Universidad Nacional del Comahue Quintral 1250, San Carlos de Bariloche (8400), Río Negro, Argentina

${ }^{4}$ Laboratorio de Investigación en Sistemas Ecológicos y Ambientales, Facultad de Ciencias Agrarias y Forestales-Facultad de Ciencias Naturales y Museo, UNLP. Diagonal 113, \#469 (1900), La Plata, Buenos Aires, Argentina

* Corresponding author: mariasvelazquez@yahoo.com.ar
} 
unstable and immature - are characterized by shallow surface soils; low temperatures but with a wide temperature range; rainfall in all four seasons; snow accumulation during at least some part of the year (i. e., between May and November in Argentina); low relative humidity; high radiation levels; strong winds; and low partial pressures of oxygen, and carbon dioxide (Ferreyra 1995). These ecosystems are home to different habitats, distributed in the form of islands (such as screes, meadows, and highaltitude steppes) that allow the development of diverse plant communities adapted to those environmental conditions. The high-Andean environments harbor more than 300 plant species (Ferreyra 1995; Ferreyra et al. 2006), of which flora little is known regarding its association with mycorrhizal fungi or other fungal endophytes.

Arbuscular mycorrhizal fungi (AMF; phylum Glomeromycota) are common soil denizens that establish an arbuscular mycorrhizal association with a great majority of land plants (Wang \& Qiu 2006). Those fungi provide several ecosystem services including promoting plant growth and nutrient uptake, increasing plant resistance to drought along with protection against biotic stresses, and enhancing soil stability and water retention (Gianinazzi et al. 2010). Therefore, that symbiotic association constitutes an key strategy for assisting plants to cope with extreme environmental conditions (Smith \& Read 2008), such as occur in high-altitude ecosystems. Previous investigations have indicated that plants occurring in the high Andes of Peru at altitudes of up to 5,391 m (Schmidt et al. 2008) and in the Bolivian Andes at heights between 3,700 and 4,000 m (Urcelay et al. 2011) are associated with AMF and dark septate endophytes. The species richness of AMF in high-altitude environments has also been reported (Lugo et al. 2008; Oehl et al. 2011a; Oehl \& Koerner 2014) and new resident species described (Oehl et al. 2012; Palenzuela et al. 2014).

Despite the ubiquitous presence of AMF in high-altitude environments, only scarce information is available on the occurrence of those fungi in the high-Andean Patagonia in Argentina. The Northwest region of the Patagonia is characterized by marked climatic and vegetation gradients. The precipitation levels range from more than $3,500 \mathrm{~mm}$ per year in the mountains of the border between Argentina and Chile, in the west, to less than $500 \mathrm{~mm}$ per year in the east (Pereyra et al. 2005). Therefore, the aim of this work was: i) to assess the occurrence and diversity of AMF associated with the rhizospheres of different plant species growing in diverse environments over an altitude gradient and ii) to investigate the effect of host-plant identity and altitude on AMF community composition. The results reported here will increase our knowledge regarding the distribution of this group of fungi and in so doing facilitate the development of strategies directed at the management and protection of these biota in the different high-mountain environments.

\section{Materials and methods}

\author{
Study site
}

The study area is located in the Northwest Patagonia within the Nahuel Huapi National Park (705,000 ha) in the Province of Río Negro, Argentina. That region - part of the Patagonian Phytogeographic Province (Cabrera \& Willink 1980; Fig. 1) - is characterized by a semiarid to subhumid climate (mean annual isotherm below $10^{\circ} \mathrm{C}$; Soriano et al. 1983), with rain and snow being concentrated in the autumn and winter seasons and a high frequency of strong westerly winds. The spring and summer, however, are cool and dry, though also windy (Ayesa et al. 1995).

Sampling design

The sites selected for this study at the national park were the Patagonian Steppe (PS), Challhuaco Hill (ChC), Catedral Hill (CH), and Tronador Hill (TH; Tab. 1). The sites are distributed over a precipitation and altitude gradient ranging from $3,500 \mathrm{~mm}$ and $3,484 \mathrm{~m}$, respectively, in the westernmost site (TH) to $500 \mathrm{~mm}$ and $830 \mathrm{~m}$, respectively, in the easternmost site (PS). Owing to differences in altitude within each site, all samples in these high-mountain environments were collected between $1.500-1,900 \mathrm{~m}$ (Tab. 1). Within each site, two to four different environments were selected (i. e., steppe, high steppe, forest, scree, timberline, and meadow). In each environment, rhizosphere-soil samples (500 g each) from three individuals of each plant species were collected. The plant individuals were selected by means of a random-walk method and were at least five meters away from each other. We selected nine plant species with different life forms plus a wide altitude distribution $(830-3500 \mathrm{~m})$ and precipitation regimen $(500-3,500$ $\mathrm{mm}$ /year; Table 1).

\section{Soil analysis}

All the individual soil samples from each environment were pooled to obtain a composite specimen to be used for physical and chemical analysis. The proportions of clay, silt, and sand were determined by the hydrometer method (Bouyocus 1962); soil pH measured in a 1:2.5 (w/v) soil-towater ratio; organic carbon assessed by the wet-oxidation method of Walkley \& Black (1934); total N estimated by the micro-Kjedahl method (Jackson 1967); and phosphorus concentration assayed by mineralization of the sample and dry digestion. All the analyses were carried out by the Soil Group from the Centro Regional Universitario Bariloche, Universidad Nacional del Comahue, Río Negro, Argentina. 


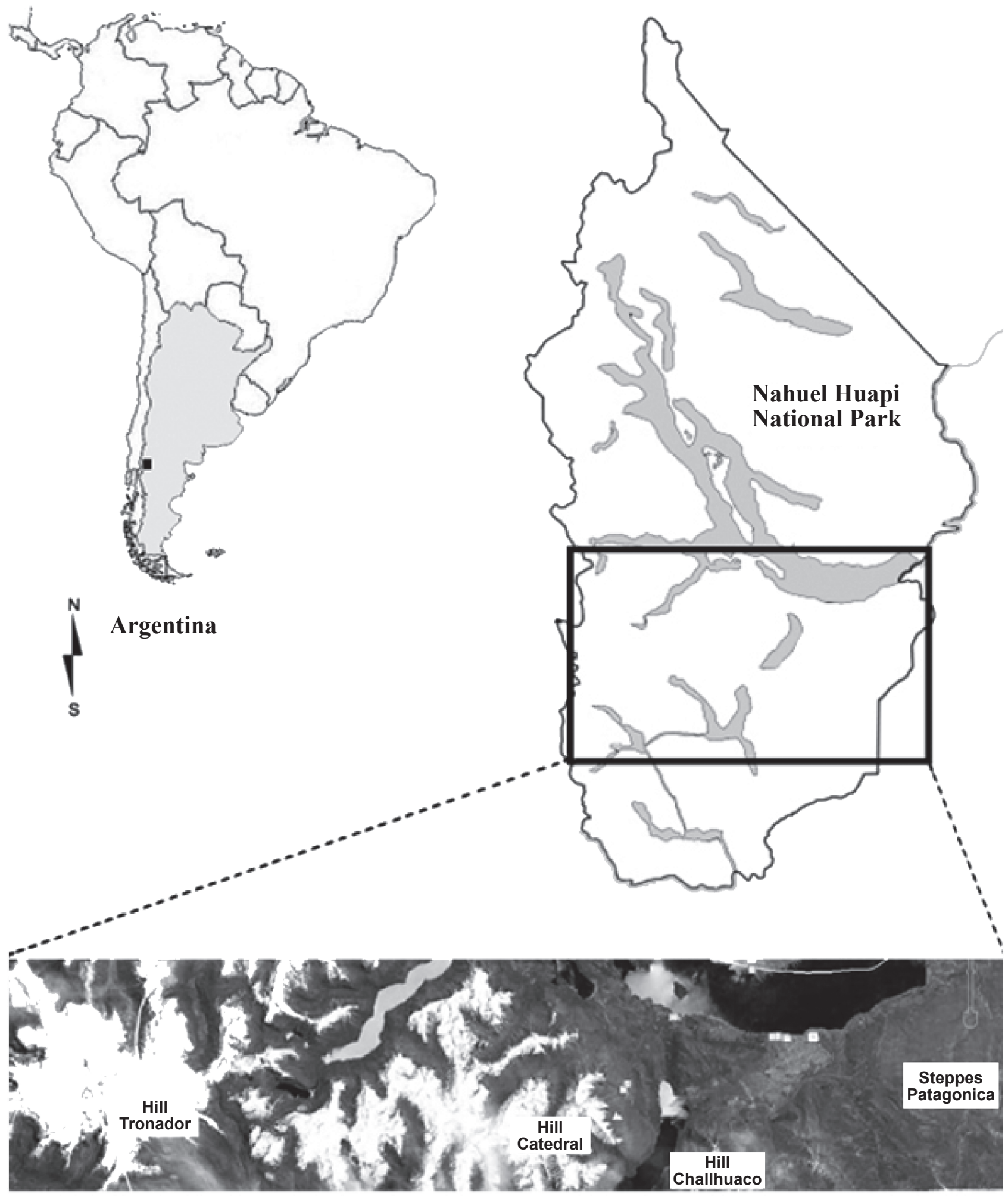

Figure 1. Map of Argentina showing the Nahuel Huapi National Park and in the detailed inset indicating the location of the sampling sites: the Patagonian Steppe, Challhuaco Hill, Catedral Hill, and Tronador Hill. 
María Silvana Velázquez, Sidney Luiz Stürmer, Clara Bruzone,

Sonia Fontenla, Marcelo Barrera and Marta Cabello

Table 1. Identification and description of the studied sites, plant species sampled and life form in the Patagonian region of Argentina.

\begin{tabular}{|c|c|c|c|c|c|}
\hline Sites & Environment & Coordinates & Altitude $[\mathrm{m}]$ & $\begin{array}{l}\text { Precipitation } \\
\text { [mm/year] }\end{array}$ & Plant species \\
\hline \multirow[t]{2}{*}{ Patagonian Steppe [PS] } & Steppe 1 (PS1) & $41^{\circ} 08^{\prime} 59^{\prime \prime} \mathrm{S}-71^{\circ} 10^{\prime} 27^{\prime \prime} \mathrm{W}$ & 830 & 500 & $\begin{array}{l}\text { Armeria maritima (Mill.) Willd. (PF), } \\
\text { Baccharis magellanica (Lam.) Pers. (DS), } \\
\text { Berberis empetrifolia Lam. (SS), Viola } \\
\text { maculata Cav. (PF) }\end{array}$ \\
\hline & Steppe 2 (PS2) & $41^{\circ} 08^{\prime} 00^{\prime \prime S}-71^{\circ} 10^{\prime} 13^{\prime \prime} \mathrm{W}$ & 838 & 500 & $\begin{array}{l}\text { Oreopulus glacialis (Poepp. \& Endl.) } \\
\text { Ricard (PF) }\end{array}$ \\
\hline \multirow[t]{4}{*}{ Challhuaco Hill (ChH] } & High steppe (HS) & $41^{\circ} 16^{\prime} 12^{\prime \prime S}-71^{\circ} 18^{\prime} 16^{\prime \prime} \mathrm{W}$ & 1770 & 1000 & A. maritima \\
\hline & Forest $(\mathrm{F})$ & - & 1629 & 1000 & Chiliotrichum rosmarinifolium Less. (SH) \\
\hline & Scree (SC) & $41^{\circ} 16^{\prime} 12^{\prime \prime S}-71^{\circ} 18^{\prime} 16^{\prime \prime} \mathrm{W}$ & 1820 & 1000 & $\begin{array}{l}\text { A. maritima, B. magellanica, } B \text {. } \\
\text { empetrifolia, Nassauvia revoluta Don. } \\
\text { (SS), Senecio bipontinii Wedd. (SS), V. } \\
\text { maculata }\end{array}$ \\
\hline & Timberline $(\mathrm{T})$ & $41^{\circ} 16^{\prime} 17^{\prime \prime} \mathrm{S}-71^{\circ} 17^{\prime} 02^{\prime \prime} \mathrm{W}$ & 1592 & 1000 & Ch. rosmarinifolium \\
\hline \multirow[t]{3}{*}{ Catedral Hill (CH) } & Scree 1 (SC1) & $41^{\circ} 10^{\prime} 51^{\prime \prime S}-71^{\circ} 28^{\prime} 10^{\prime \prime} \mathrm{W}$ & 2005 & 1500 & $\begin{array}{l}\text { B. magellanica, } N \text {. revoluta, } \\
\text { Quinchamalium chilense (PF), S. } \\
\text { bipontinii }\end{array}$ \\
\hline & Scree 2 (SC2) & $41^{\circ} 10^{\prime} 20^{\prime \prime} \mathrm{S}-71^{\circ} 18^{\prime} 56^{\prime \prime} \mathrm{W}$ & 1886 & 1500 & A. marítima \\
\hline & Meadow (M) & $41^{\circ} 10^{\prime} 20^{\prime \prime S}-71^{\circ} 18^{\prime} 56^{\prime \prime} \mathrm{W}$ & 1892 & 1500 & Ch. rosmarinifolium \\
\hline \multirow[t]{2}{*}{ Tronador Hill (TH) } & Scree (SC) & $41^{\circ} 10^{\prime} 33^{\prime \prime S}-71^{\circ} 49^{\prime} 04^{\prime \prime} \mathrm{W}$ & 1901 & 3500 & $\begin{array}{l}\text { A. maritima, B. empetrifolia, } B . \\
\text { magellanica, Ch. rosmarinifolium, } N \text {. } \\
\text { revoluta, Q. chilense, S. bipontinii }\end{array}$ \\
\hline & Meadow (M) & $41^{\circ} 10^{\prime} 33^{\prime \prime} \mathrm{S}-71^{\circ} 49^{\prime} 04^{\prime \prime} \mathrm{W}$ & 1883 & 3500 & Ch. rosmarinifolium \\
\hline
\end{tabular}

PF: perennial forb. SS: subscrub. DS: dwarf scrub. SH: shrub

\section{AMF spore isolation and identification}

AMF spores were extracted from 100-g aliquots of each rhizosphere sample, for a total of 75 samples. Soil was wetsieved and decanted (Gerdemann \& Nicolson 1963) and the supernatant centrifuged in a sucrose gradient (Walker et al. 1982). Only apparently healthy spores were counted on a Petri dish by direct observation under a dissecting microscope. For identification, each spore type was mounted in polyvinyl-lactic acid - glycerine (PVLG; Koske \& Tessier 1983) and the PVLG mixed with Melzer's reagent (Brundrett et al. 1994). The spores were identified at the genus and species level on the basis of spore-wall structure, Melzer's reaction, spore size and color, and the presence of sporewall ornamentation. Spore morphology was compared with on-line descriptions of the INternational Culture Collection of (Vesicular) Arbuscular Mycorrhizal Fungi (INVAM) at West Virginia University, USA (http://invam.caf.wvu. edu) and the Department of Plant Pathology, University of Agriculture in Szczecin, Poland (www.agro.ar.szczecin. $\mathrm{pl} /$ jblaszkowski/). The assignment of AMF morphotypes to families and genera followed the consensus classification of Redecker et al. (2013).

\section{Analysis of the structure of AMF species and communities}

On the basis of spore counting and the presence-versusabsence data, we calculated the following parameters: $i$ ) the total number of spores: the total number of spores from all the species occurring in a sample, ii) the relative species abundance: the ratio of the number of spores from a particular species with respect to the total number of spores recovered, and iii) the frequency of occurrence (FO): percentage of samples from which spores of a particular species were recovered. Following Zhang et al. (2004), we classified AMF species according to their frequency as dominant $(\mathrm{D}=\mathrm{FO}>50 \%)$, most common $(\mathrm{MC}=30 \%<\mathrm{FO} \leq$ $50 \%)$, common $(\mathrm{C}=10 \%<\mathrm{FO} \leq 30 \%)$, and rare $(\mathrm{R}=\mathrm{FO} \leq 10$ $\%)$. Species richness is represented by the total number of species recovered at each site; species abundance was used to calculated Shannon's (H) diversity (Magurran 2004). 
A dendogram displaying the similarity in AMF-species composition among the host plants in all the ecosystems was obtained by cluster analysis. The group-average-clustering method and the squared-Euclidean metric distance were used. The clustering analysis was performed with the Multivariate Statistical Package (MVSP 3.1).

\section{Statistical analysis}

Spore numbers were transformed to a $\log (x+1)$ function before analysis. The number of spores and the species richness were subjected to a one-way analysis of variance (ANOVA). When the F ratio of the ANOVA was significant, the mean values were compared by Tukey's ad-hoc test with the JMP software. The Shannon index of diversity was compared among the sites by the Past software (Hammer et al. 2001). Regression analysis was performed to verify the correlation between species richness, spore numbers, and altitude.

\section{Results}

\section{Soil analysis}

The soil texture at all the sites ranged from sandy to sandy loam, with the $\mathrm{pH}$ ranging from 5.9 to 6.3 (Tab. 2). The concentration of soil carbon at most sites ranged from $0.54 \%$ to $2.42 \%$, except in the meadow at TH $(4.07 \%)$ and in the forest at $\mathrm{ChH}(8.23 \%)$. The concentration of nitrogen was $<1 \%$ in all environments; while the soil-phosphorus content was $<2.0 \mathrm{mg} / \mathrm{kg}$, except in the high steppe, forest, and timberline environments at $\mathrm{ChH}$, where the values varied from 7.95 up to $26.40 \mathrm{mg} / \mathrm{kg}$.

\section{Species composition}

Spores from a total of 27 species were recovered from all the sites. The three spore specimens that could not be attributed to known species were therefore identified at the genus level (Table 3). The species thus characterized belonged to the following genera (and families): Acaulospora (Acaulosporaceae); Dentiscutata, Cetraspora, and Scutellospora (Gigasporaceae); Pacispora (Pacisporaceae); Funneliformis, Glomus, and Rhizophagus (Glomeraceae); Claroideoglomus (Claroideoglomeraceae); and Ambispora (Ambisporaceae) - spanning three of the four orders within the Glomeromycota phylum (Tab. 3). Most of the species belonged to the Acaulosporaceae (12 species) followed by the Glomeraceae (five species). Entrophospora infrequens was detected at only one site $(\mathrm{ChH})$ but was not allocated to any family, as that species is considered incertae sedis by Redecker et al. (2013).

Only five species were considered to be dominant, with four pertaining to the genus Acaulospora (Tab. 3). Acaulospora laevis was dominant at all sites, whereas $A$. dilatata and $A$. scrobiculata were dominant at only $\mathrm{CH}$ and TH. Acaulospora delicata was dominant at $\mathrm{PS}, \mathrm{ChH}$, and $\mathrm{CH}$ but only common at TH; and Glomus sp. 1 was dominant at only TH. Exclusive species detected at only one site were A. rehmii, Acaulospora sp. 1 Dentiscutata biornata, and Entrophospora infrequens at $\mathrm{ChH} ; \mathrm{A}$. bireticulata and D. heterogama at $\mathrm{CH}$; and $\mathrm{A}$. foveata at TH (Tab. 3). Fungi that contributed to over $10 \%$ of the spores isolated were all members of Acaulospora: A. laevis (23.1\%), A. dilatata (16.7\%), A. delicata (13.7\%), and A. scrobiculata (15.0\%).

The presence and relative spore abundance of each family of Glomeromycota varied according to site and plant host (Fig. 2). At PS, only three of the six families were detected while at $\mathrm{CH}$ and $\mathrm{TH}$ all six families were represented. Spores

Table 2. Physical and chemical attributes of soil sampled in the Patagonian region of Argentina.

\begin{tabular}{|c|c|c|c|c|c|c|c|c|c|c|}
\hline \multirow{2}{*}{ Sites } & \multirow{2}{*}{ Environment } & \multirow[t]{2}{*}{$\mathrm{pH}$} & \multirow{2}{*}{$\begin{array}{c}\text { C } \\
{[\%]}\end{array}$} & \multirow{2}{*}{$\begin{array}{c}\mathrm{N} \\
{[\%]}\end{array}$} & \multirow{2}{*}{$\begin{array}{c}P \\
{[\mathrm{mg} / \mathrm{kg}]}\end{array}$} & \multirow{2}{*}{$\begin{array}{c}\text { CEC } \\
\text { [cmolc/kg] }\end{array}$} & \multicolumn{3}{|c|}{ Fine fraction [\%] } & \multirow{2}{*}{ Texture } \\
\hline & & & & & & & Clay & Slit & Sand & \\
\hline \multirow[t]{2}{*}{ Patagonian Steppe (PS) } & Steppe 1 & 6.3 & 2.42 & 0.19 & 1.7 & 14 & 8.5 & 16.3 & 68.6 & Sandy loam \\
\hline & Steppe 2 & 6.0 & 1.56 & 0.13 & 0.4 & 9.6 & 4.6 & 12.1 & 79.9 & Sandy loam \\
\hline \multirow[t]{4}{*}{ Challhuaco Hill $(\mathrm{ChH})$} & High Steppe & 6.6 & 1.73 & 0.13 & 12 & 6 & 3.2 & 5.5 & 89.7 & Sandy \\
\hline & Forest & 6.0 & 8.23 & 0.33 & 26.40 & 26.4 & 9 & 19.3 & 65.5 & Sandy loam \\
\hline & Scree & 6.1 & 1.13 & 0.8 & 0.9 & 7.2 & 4.7 & 6.9 & 86.4 & Sandy loam \\
\hline & Timberline & 6.1 & 2.05 & 0.16 & 7.95 & 32 & 17.6 & 18.4 & 59.7 & Sandy loam \\
\hline \multirow[t]{3}{*}{ Catedral Hill (CH) } & Scree 1 & 6.0 & 0.89 & 0.06 & 1.1 & 6 & 31 & 7.1 & 88.2 & Sandy \\
\hline & Scree 2 & 6.1 & 1.02 & 0.07 & 1.1 & 7.6 & 3.8 & 7 & 87 & $\begin{array}{c}\text { Sandy to sandy } \\
\text { loam }\end{array}$ \\
\hline & Meadow & 5.9 & 2.17 & 0.14 & 1.2 & 13.4 & 5.2 & 6.9 & 84 & Sandy loam \\
\hline \multirow[t]{2}{*}{ Tronador Hill (TH) } & Scree & 5.9 & 0.54 & 0.08 & 1.9 & 10.2 & 2.9 & 8.4 & 83.5 & Sandy loam \\
\hline & Meadow & 6.1 & 4.07 & 0.26 & 0.3 & 11 & 5.6 & 7.9 & 83.6 & Sandy loam \\
\hline
\end{tabular}




\section{María Silvana Velázquez, Sidney Luiz Stürmer, Clara Bruzone, \\ Sonia Fontenla, Marcelo Barrera and Marta Cabello}

Table 3. Frequency of occurrence and overall relative abundance ( $n=75)$ of AMF species detected in distinct sites in Nahuel Huapi National Park, Patagonia, Argentina. Within each site, AMF species frequency was categorized as dominant (D), most common (MC), common $(C)$, and rare $(\mathrm{R})$.

\begin{tabular}{|c|c|c|c|c|c|}
\hline $\begin{array}{l}\text { Families } \\
\text { AMF species }\end{array}$ & $\begin{array}{l}\text { Patagonian Steppe } \\
\text { (PS) }[n=15]\end{array}$ & $\begin{array}{l}\text { Chalhuaco Hill } \\
\text { (ChH) }[n=21]\end{array}$ & $\begin{array}{c}\text { Tronador Hill (TH] } \\
{[n=21]}\end{array}$ & $\begin{array}{l}\text { Catedral Hill (CH) } \\
\text { (n=18) }\end{array}$ & $\begin{array}{l}\text { Overall relative } \\
\text { abundance [\%] }\end{array}$ \\
\hline \multicolumn{6}{|l|}{ Acaulosporaceae } \\
\hline Acaulospora alpina Oehl, Sykorova \& Sieverd & $\mathrm{R}$ & $\mathrm{R}$ & MC & C & 3.70 \\
\hline A. bireticulata Rothwell \& Trappe & - & - & - & $\mathrm{R}$ & 0.11 \\
\hline A. cavernata Błaszk. & $\mathrm{R}$ & - & C & C & 2.31 \\
\hline A. delicata Walker, Pfeiff. \& Bloss & $\mathrm{D}$ & $\mathrm{D}$ & C & $\mathrm{D}$ & 13.65 \\
\hline A. dilatata Morton & C & C & $\mathrm{D}$ & $\mathrm{D}$ & 16.73 \\
\hline A. foveata Trappe \& Janos & - & - & $\mathrm{R}$ & - & 0.06 \\
\hline A. laevis Gerd. \& Trappe & $\mathrm{D}$ & $\mathrm{D}$ & $\mathrm{D}$ & $\mathrm{D}$ & 23.06 \\
\hline A. mellea Spain \& Schenck & MC & MC & - & C & 6.98 \\
\hline A. rehmii Sieverd. \&Toro & - & $\mathrm{R}$ & - & - & 0.11 \\
\hline A. scrobiculata Trappe & $\mathrm{R}$ & C & $\mathrm{D}$ & $\mathrm{D}$ & 15.02 \\
\hline A. spinosa Walker \& Trappe & MC & - & C & C & 3.00 \\
\hline Acaulospora sp. 1 & - & $\mathrm{R}$ & - & - & 0.40 \\
\hline \multicolumn{6}{|l|}{ Gigasporaceae } \\
\hline $\begin{array}{l}\text { Dentiscutata biornata (Spain, Sieverd. \& Toro) } \\
\text { Sieverd., F.A. Souza \& Oehl }\end{array}$ & - & $\mathrm{R}$ & - & - & 0.26 \\
\hline $\begin{array}{l}\text { D. heterogama (Nicolson \& Gerd.) Sieverd., } \\
\text { F.A. Souza \& Oehl }\end{array}$ & - & - & - & $\mathrm{R}$ & 0.37 \\
\hline $\begin{array}{l}\text { Cetraspora gilmorei (Trappe \& Gerd.) Oehl, } \\
\text { F.A. Souza \& Sieverding }\end{array}$ & C & $\mathrm{R}$ & - & $\mathrm{R}$ & 1.54 \\
\hline Scutellospora sp. 1 & $\mathrm{R}$ & - & $\mathrm{R}$ & - & 0.51 \\
\hline \multicolumn{6}{|l|}{ Pacisporaceae } \\
\hline $\begin{array}{l}\text { Pacispora patagonica (Novas \& Fracchia) } \\
\text { Walker, Vestberg \& Schüssler }\end{array}$ & - & - & $\mathrm{R}$ & $\mathrm{R}$ & 0.08 \\
\hline \multicolumn{6}{|l|}{ Glomeraceae } \\
\hline $\begin{array}{l}\text { Funneliformis mosseae (Nicolson \& Gerd.) } \\
\text { Walker \& Schüssler }\end{array}$ & C & - & - & $\mathrm{R}$ & 0.17 \\
\hline G. microaggregatum Koske, Gemma \& Olexia & - & - & $\mathrm{R}$ & $\mathrm{R}$ & 0.40 \\
\hline G. tortuosum Schenck \& Sm. & - & $\mathrm{R}$ & C & - & 0.14 \\
\hline Glomus sp. 1 & MC & MC & $\mathrm{D}$ & $\mathrm{R}$ & 3.82 \\
\hline $\begin{array}{l}\text { Rhizophagus clarus (Nicolson \& Schenck) } \\
\text { Walker \& Schüssler }\end{array}$ & $\mathrm{R}$ & - & - & $\mathrm{R}$ & 0.11 \\
\hline \multicolumn{6}{|l|}{ Claroideoglomeraceae } \\
\hline $\begin{array}{l}\text { Claroideoglomus claroideum (Schenck \& Sm.) } \\
\text { Walker \& Schüssler }\end{array}$ & - & C & C & - & 0.71 \\
\hline $\begin{array}{l}\text { C. etunicatum (Becker \& Gerd.) } \\
\text { Walker \& Schüssler }\end{array}$ & - & $\mathrm{R}$ & MC & C & 3.53 \\
\hline \multicolumn{6}{|l|}{ Ambisporaceae } \\
\hline $\begin{array}{l}\text { Ambispora leptoticha (N.C. Schenck\& G.S. Sm.) } \\
\text { R.J. Bills \& J.B. Morton }\end{array}$ & - & - & - & C & 0.91 \\
\hline $\begin{array}{l}\text { A. gerdemannii (S.L. Rose, B.A. Daniels \& Trappe) } \\
\text { R.J. Bills \& J.B. Morton }\end{array}$ & - & $\mathrm{R}$ & MC & $\mathrm{R}$ & 2.25 \\
\hline \multicolumn{6}{|l|}{ Incertae sedis (of uncertain position) } \\
\hline Entrophospora infrequens (Hall) Ames \& Schneid. & - & $\mathrm{R}$ & - & - & 0.06 \\
\hline Total AMF spore number $(\mathrm{N})$ & $45.8 \mathrm{ab}^{1)}$ & $27.3 \mathrm{~b}$ & $43.2 \mathrm{ab}$ & $91.7 \mathrm{a}$ & \\
\hline Species richness $(S)$ & $3.8 \mathrm{a}$ & $4.4 \mathrm{a}$ & $3.3 \mathrm{a}$ & $4.4 \mathrm{a}$ & \\
\hline Shannon's index $(\mathrm{H})$ & $2.11 \mathrm{ab}$ & $2.16 \mathrm{a}$ & $1.94 \mathrm{c}$ & $2.05 \mathrm{~b}$ & \\
\hline
\end{tabular}

${ }^{1)}$ Values followed by different letters in a row indicate significant differences at $\mathrm{P}<0.05$ based on Tukey's post hoc tests $(\mathrm{P}<$ 0.05 ) for total spore numbers and species richness, and on $\mathrm{t}$ test for $\mathrm{H}$. 
A
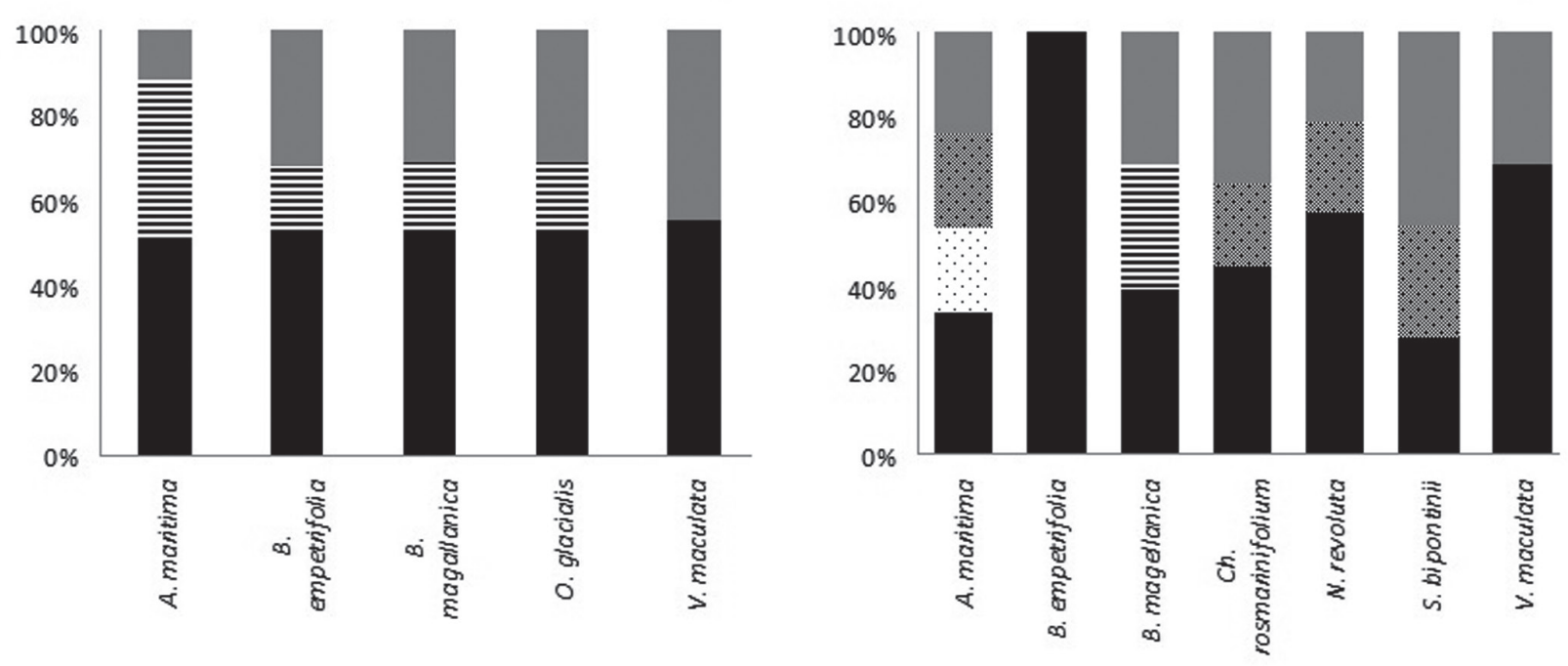

C
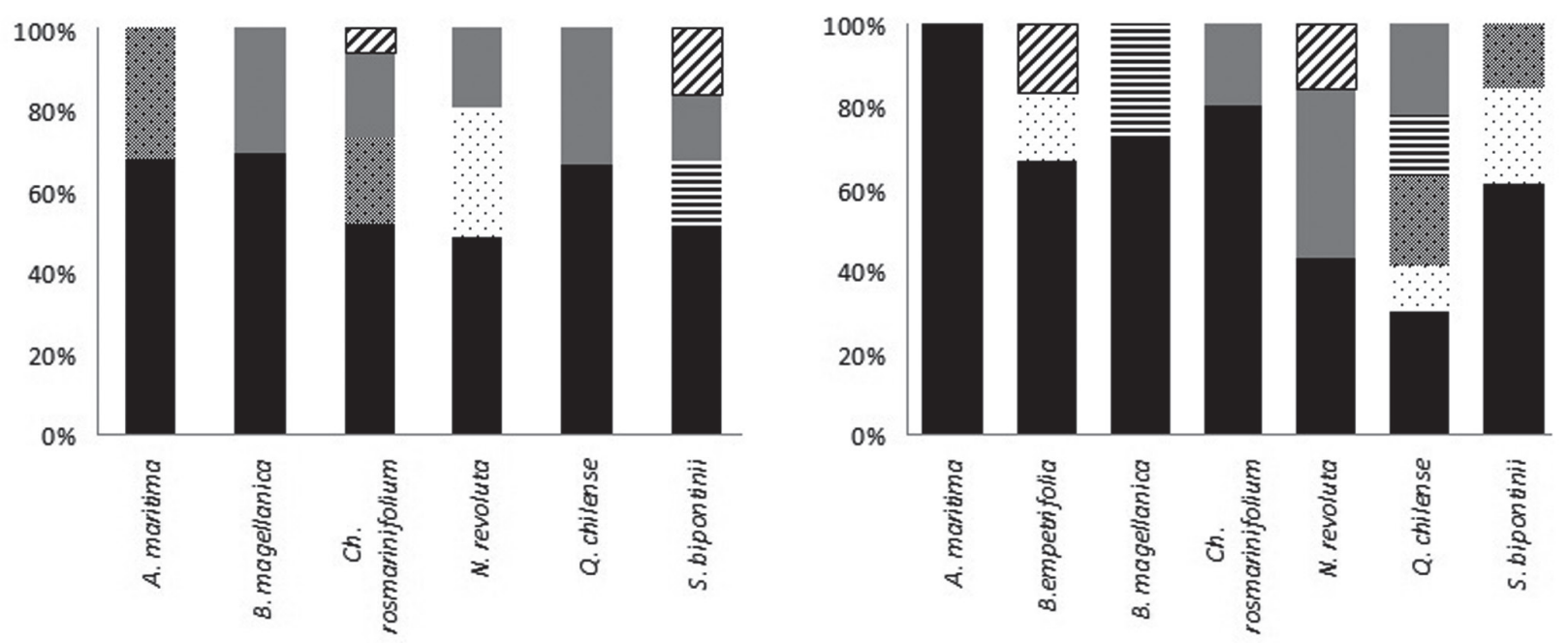

Figure 2. Percentage of spores produced by fungi from each of the following families of Glomeromycota in (A) Patagonian Steppe, (B) Challhuaco Hill, (C) Catedral Hill, and (D) Tronador Hill: Acaulosporaceae (solid black bars), Glomeraceae (solid gray bars), Gigasporaceae (horizontally hatched bars), Pacisporaceae (diagonally hatched bars), Ambisporaceae (white stippled bars), and Claroideoglomeraceae (gray stippled bars).

of Pacisporaceae occurred only at $\mathrm{CH}$ and $\mathrm{TH}$ in association with four host plants, and those of Ambisporaceae were not detected at PS. A. maritima and B. magellanica were the only host plants present at all the sites, but the relative abundance of each family associated with them varied among the sites (Fig. 2). A. maritima was associated with Gigasporaceae at only PS but was in symbiosis exclusively with Acaulosporaceae at TH. B. magellanica was associated with three families at PS and $\mathrm{ChH}$ (Acaulosporaceae, Gigasporaceae, and Glomeraceae) and with two families at $\mathrm{CH}$ and TH. V. maculata had only Acaulosporaceae and Glomeraceae as symbionts at both PS and $\mathrm{ChH}$. Finally,
Q. chilense was associated with only Acaulosporaceae and Glomeraceae at $\mathrm{CH}$ but with five out of the six families (save Pacisporaceae) at TH (Fig. 2).

\section{AMF spore abundance and diversity}

The mean number of AMF spores was highly variable among the different ecosystems within each site and ranged on the average from 4.5 (the forest in $\mathrm{ChH}$ ) to 107.1 (the scree in $\mathrm{CH}$ ). No significant difference was detected in total number of spores at sites $\mathrm{PS}, \mathrm{TH}$, and $\mathrm{CH}$; whereas the 


\section{María Silvana Velázquez, Sidney Luiz Stürmer, Clara Bruzone, Sonia Fontenla, Marcelo Barrera and Marta Cabello}

number of spores at $\mathrm{ChH}$ was significantly lower than at $\mathrm{CH}$ (Tab. 3). The correlation between AMF spore numbers and altitude was not significant $\left(r^{2}=0.003, p=0.63, y=3.206841\right.$ + 0.0001325 x; Fig. 3A)

The AMF species richness was also highly variable among the different ecosystems - ranging from 3 species in steppe in PS and forest in $\mathrm{ChH}$ ) up to 17 in the scree in $\mathrm{CH}$ - and was not significantly different among the sites (Tab. 3). Furthermore, the correlation between species richness and altitude was also not significant $\left(r^{2}=0.0002\right.$, $p=0.99, y=4.004922-0.000003 x ;$ Fig. 3B). Shannon's index of diversity tended to be higher in sites at lower elevations (i. e., PS and $\mathrm{ChH}$ ), although no differences in the index were detected between PS and $\mathrm{CH}$ (Tab. 3).

Cluster analysis indicated that the AMF communities were grouped according to sites and not by plant species: three main clusters resulted (Fig. 4). The AMF community at $\mathrm{CH}$ formed a different group from those at the other sites. A second cluster was formed with most samples from $\mathrm{TH}$ and $\mathrm{PS}$ and half of the samples from $\mathrm{ChH}$. The AMF-community composition at $\mathrm{ChH}$ was quite similar to the one at PS.
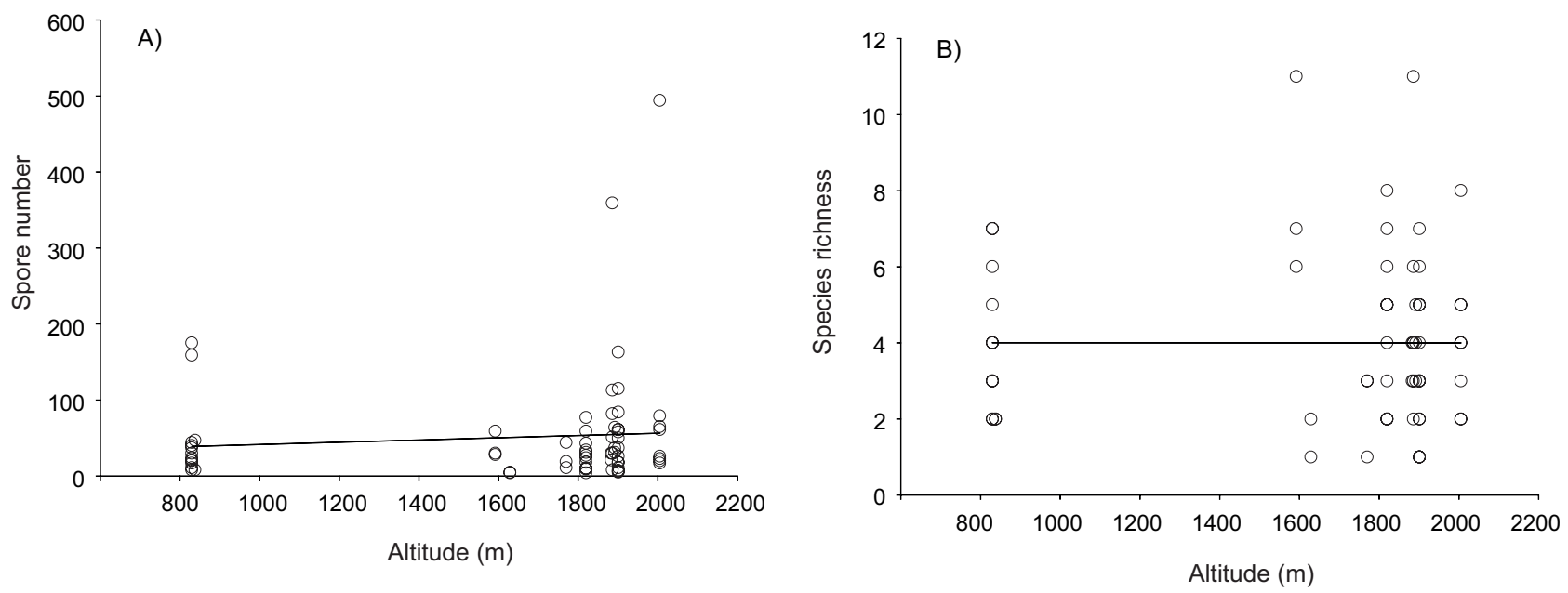

Figure 3. Correlation between altitude and AMF spore number (A) and species richness (B) at eleven environments in the Nahuel Huapi National Park.

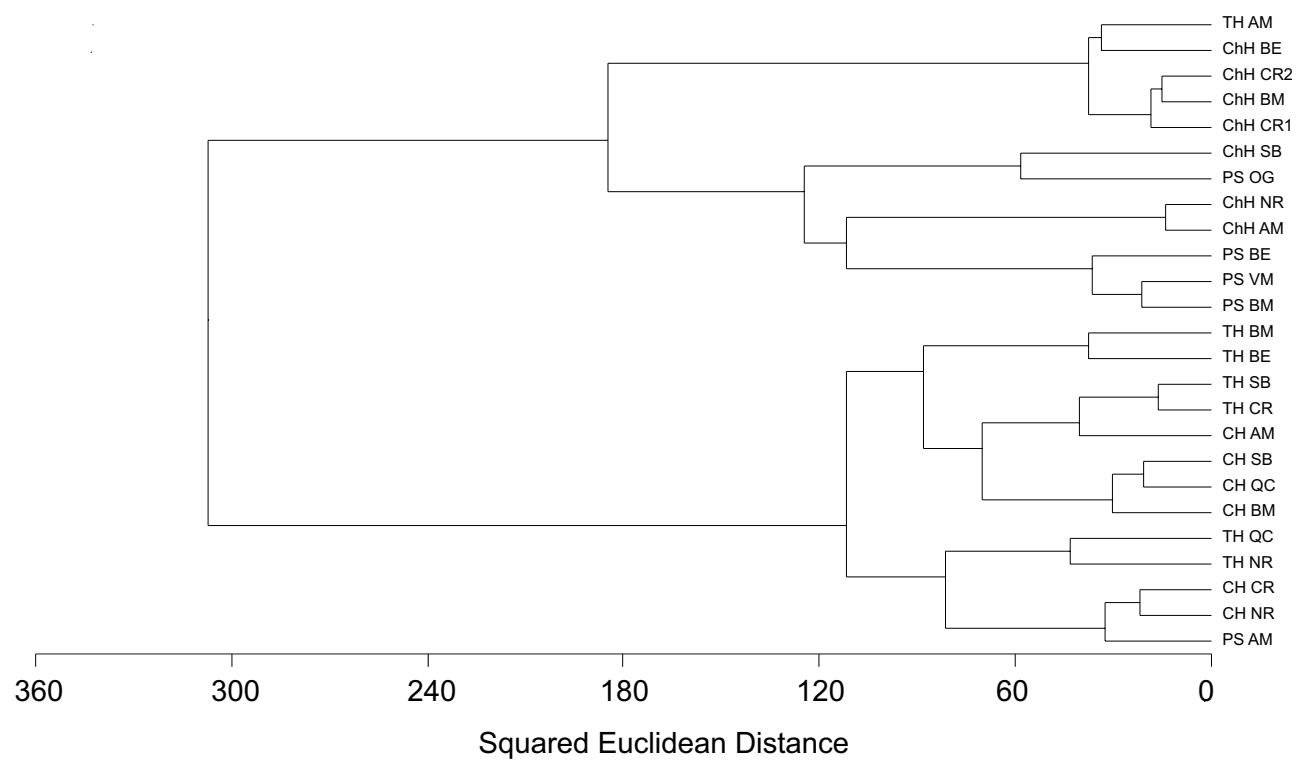

Figure 4. Dendogram of cluster analysis based on the similarity of AMF-community composition according to the host plants and sites. The group-average - clustering method was used in combination with the squared Euclidean metric distance. Abbreviations: Sites: Patagonian Steppe (PS), Challhuaco Hill (ChH), Catedral Hill (CH), Tronador Hill (TH). Host-plant species: Armeria maritima (AM), Berberis empetrifolia (BE), Baccharis magellanica (BM), Chilliotrichum rosmarinifolium (CR), Nassauvia revoluta (NR), Oreopulus glacialis (OG), Quinchamalium chilense (QC), Senecio bipontinii (SB), Viola maculata (VM). 


\section{Discussion}

We characterized the AMF community composition and determined the spore diversity among field-collected spores at four sites from the Nahuel Huapi National Park in the Patagonian region of Argentina. Previous reports carried out in steppes, forests, and high-mountain regions of Patagonia had focussed on root colonization and had indicated that most plant species are colonized by AMF (Fontenla et al. 1998; 2001; Bidartondo et al. 2002; Fernández \& Fontenla 2010; Nouhra et al. 2011). Our study - therefore representing the first assessment of the species of AMF spores in soils of this region that has spanned different environments and altitudes - evidenced a diverse AMF community associated with a variety of plant hosts. Differences in AMF communities among sites were detected mainly by changes in the frequency of occurrence of species of fungal spores and thus the presence of specific families within the Glomeromycota. Although we recognize that our data are based on field-collected spores and thus represent only a frozen moment documenting the species sporulating at the sampling time, the present study constitutes the first report of AMF species richness from those environments based on extensive sampling (i. e., 75 samples from four sites in 11 different environments).

Ecologically extreme environments limit the development of most living organisms, creating demanding conditions where only certain groups with specific strategies can overcome these limitations and proliferate (Madigan et al. 2003). The total of 27 species and 10 genera within 6 families detected in the present study is in accordance with most previous investigations of high-altitude environments. In the Swiss eastern-central Alps, Oehl et al. (2011b) recovered $28 \mathrm{AMF}$ species comprising 8 genera from over seven sites ranging from altitudes of 1,922 to $2,012 \mathrm{~m}$ above sea level. In the Tibetan plateau, up to between 3,500 and $5,200 \mathrm{~m}$ of altitude, $23 \mathrm{AMF}$ species representing 10 genera were detected by Gai et al. (2009); while Liu et al. (2011) recorded a total of 21 AMF phylotypes in 6 genera from other high-altitude alpine environments. In addition |, 42 species from 11 genera were registered from the rupestrian fields in over five different habitat types ranging from 1,121 to $1,192 \mathrm{~m}$ of altitude in southeastern Brazil (Carvalho et al. 2012). In Argentina, Lugo et al. (2008) detected 10 species and 4 genera over a transect of altitudes ranging from 3,320 to $3,870 \mathrm{~m}$.

Comparisons between studies in high-altitude environments must be done with caution and after considering the different plant communities, soil types, and characteristics of the climate that can influence the composition of AMF communities. Nevertheless, results from this and other studies suggest that, despite the harsh climatic conditions of high altitudes, a diverse AMF community becomes associated with the plants in this environment.
Acaulosporaceae was the dominant family in the environments of this study in terms of species richness and relative abundance. Indeed, $44 \%$ of all the species recovered and $85 \%$ of the total number of spores came from fungi of this family. This result contrasts with all other studies based on field-spore recoveries in high-altitude environments where members of the Glomeraceae dominated (Gai et al. 2009; Oehl et al. 2011a; Carvalho et al. 2012). Acaulospora species in particular have been well documented in protected areas, representing there $75.7 \%$ of all the species described so far (Velázquez et al. 2008; 2010; Turrini \& Giovannetti 2012). Our results evidenced the predominance of that genus with respect to a National Park in Argentina. Nevertheless, certain species detected in our study were in common with those registered in at least two other studies in high-altitude environments - namely, A. laevis, A. mellea, A. scrobiculata, A. spinosa, and Entrophospora infrequens. Claroideoglomus etunicatum and C. claroideum were the only two species detected in this work that were also found in fungal communities from the Swiss Alps, the Tibetan plateau, and the Brazilian rupestrian fields. Both those species have a pandemic distribution (S.L Stürmer, personal communication) and possibly represent organisms with a high physiologic plasticity that are accordingly adaptable to a wide range of environmental conditions.

Studies on plant and animal distribution over altitude gradients have demonstrated a skewed pattern of richness as a function of altitude; with species richness first increasing with altitude, then passing through a peak, and finally declining (Cox \& Moore 2010). Studies with AMF distribution over altitude gradients in particular, however, exhibit a contrasting pattern with respect to spore abundance and species richness. For example, spore abundance has been found to decrease with increasing elevation (Gai et al. 2012) but also to pass through a maximum at an intermediate altitude (Li et al. 2014; Coutinho et al. 2015). AMF species richness furthermore has been reported as not affected (Li et al. 2014) or decreasing (Lugo et al. 2008; Gai et al. 2012) with increased elevation or has been observed to peak at intermediate altitudes in an altitude gradient (Coutinho et al. 2015). In contrast, the present study has indicated no correlation between AMF spore number and species richness with increasing altitude (Fig. 3 ). We disagree with the conclusion of Gai et al. (2012) that a general pattern of AMF diversity and abundance over gradients in elevation can be detected worldwide. Our results along with recently published studies (Li et al. 2014; Coutinho et al. 2015) contrast with the patterns found by others (Lugo et al. 2008; Schmidt et al. 2008), thus suggesting that the variation in spore abundance and species richness over altitude gradients is, in fact, site-dependent and that variable conditions among those common to mountain environments - e. g., low temperatures, rainfall and moisture regimes, and frosting influence the abundance and richness of AMFs in different ways. 
The cluster analysis based on similarity (presence/ absence) provided evidence that the AMF communities had become grouped according to the different sites $-e$. g., the communities at PS tended to cluster with those at $\mathrm{ChC}$, whereas and those from $\mathrm{TH}$ and $\mathrm{CH}$ clustered together - and not with respect to the host plants present. For instance, the AMF communities associated with Armeria maritima occurring in all sites were very dissimilar, as illustrated by the position of sites where this plant occurred in the terminal nodes of the cluster analysis (Fig. 4). Our results contrast with those found by Liu et al. (2015) in Tibetan alpine grasslands, where the plant communities (in terms of type, cover, and density) contributed to the differences in location of the AMF communities. The present results denote a difference in AMF-community composition between sites at lower altitudes (i. e., PS and $\mathrm{ChC}$ ) and those at the higher altitudes (i. e., $\mathrm{CH}$ and $\mathrm{TH}$ ), where the environmental conditions were more extreme (e. g., a higher precipitation in the form of rain and snow).

In summary, our study of AMF communities at highaltitude sites in the Patagonian region of Argentina led to the following conclusions: i) Acaulosporaceae was the dominant family in terms of species richness and spore abundance. ii) Most of the Glomeromycota families detected in this work were present at all sites regardless of altitude. iii) The same plant hosts harbored AMF communities that were specific to the different sites. iv) The AMF species richness and spore numbers did not change with increasing elevation. Differences in species diversity and composition between regions that share similar environmental conditions suggest that geographical and historical (i. e., dispersion and speciation) influences are fundamental in determining local diversity (Ricklefs \& Schluter 1993). While certain patterns of AMF-community structure obtained in the present investigation were comparable to those of other studies from high-altitude environments, other community-structural configurations were unique to this study, suggesting that such historical conditions are determinant in shaping AMF community composition in this environment. The diversity of AMF species reported here for the first time from a National Park in the Patagonian region provides additional information on the biodiversity of these fungi and contributes to our knowledge concerning their biogeography. These data should be taken into consideration in the establishment of policies for the conservation of these sites since the AMF communities constitute a fundamental and irreplaceable component of the soil biota.

\section{Acknowledgements}

The authors thank the authorities from National Parks for providing permits to do this study in Nahuel Huapi National Park. This research was supported by grants from UNLP (11/N773) Project, CICPBA, Agencia de Promoción Científica y Tecnológica (PICT 2007-01233). SLS thanks the
CNPq for a Research Assistantship (Process 309.163/20153) and Research Grant (Process 483.657/2011-5). MCN is research from CICPBA. Dr. Donald F. Haggerty, a retired academic investigator and native English speaker, edited the final version of the manuscript.

\section{References}

Ayesa D, Bran D, López C, Cingolani S, Clayton S, Sbriller D. 1995. Evaluación del estado actual de la desertificación en la transecta Río Negro. In: INTA (Instituto Nacional de Tecnología Agropecuaria), GTZ (Sociedad Alemana de Cooperación Técnica) (eds). Lucha Contra la Desertificación en la Patagonia. Informe Final del Proyecto de Cooperación Técnica entre la República Argentina y la República Federal Alemana. Río Gallegos, INTA/GTZ. p. 153-173.

Bidartondo ML, Redecker D, Hijri I, et al. 2002. Epiparasitic plants specialized on arbuscular mycorrhizal fungi. Nature 419: 389-392.

Bouyocus BJ. 1962. Hydrometer method improved for making particle size analysis of soil. Agronomy Journal 54: 464-465.

Brundrett M, Melville L, Peterson L. 1994. Practical methods in mycorrhiza research. Sidney, Mycologue Publications.

Cabrera AL, Willink A. 1980. Biogeografía de América Latina. In: Chesneau (ed.) Monografía No. 13, Washington, Secretaría General de la Organización de los Estados Americanos, Programa Regional de Desarrollo Científico y Tecnológico. p. 122.

Carvalho F, Souza FA, Carrenho R, Moreira FMS, Conçeição J, Fernandes GW. 2012. The mosaic of habitats in the high-altitude Brazilian rupestrian fields is a hostpot for arbuscular fungi. Applied Soil Ecology 52: 9-19.

Coutinho ES, Fernandes GW, Berbara R, Valério HM, Goto BT. 2015. Variation of arbuscular mycorrhizal fungal communities along an altitudinal gradient in rupestrian grasslands in Brazil. Mycorrhiza 25: 627-638.

Cox CB, Moore PD. 2010. Biogeography - an ecological and evolutionary approach. New Jersey, John Wiley \& Sons, Inc.

Fernández N, Fontenla S. 2010. Mycorrhizal status of obligate and facultative epiphytic ferns in a Valdivian temperate forest of Patagonia, Argentina. American Fern Journal 100: 16-26.

Ferreyra MV. 1995. Comparación de la flora y vegetación Alto-andina a lo largo de una transecta longitudinal en el Parque Nacional Nahuel Huapi, Argentina. Degree Thesis, Universidad Nacional del Comahue, Argentina.

Ferreyra M, Ezcurra C, Clayton S. 2006. Flores de Alta Montaña de los Andes Patagónicos. Buenos Aires, Editorial LOLA.

Fontenla S, Godoy R, Rosso P, Havrylenko M. 1998. Root associations in Austrocedrus chilensis forests and seasonal dynamics of arbuscular mycorrhizas. Mycorrhiza 8: 29-33.

Fontenla S, Puntieri J, Ocampo JA. 2001. Mycorrhizal associations in the Patagonian steppe, Argentina. Plant Soil 233: 13-29.

Gai JP, Christie P, Cai XB, et al. 2009. Occurrence and distribution of arbuscular mycorrhizal fungal species in three types of grassland community of the Tibetan Plateau. Ecological Research 24: 1345-1350.

Gai JP, Tian H, Yang FY, Christie P, Li XL, Klironomos JN. 2012. Arbuscular mycorrhizal fungal diversity along a Tibetan elevation gradient. Pedobiologia 55: 145-151.

Gerdemann JW, Nicholson TH. 1963. Spores of mycorrhizal Endogone species extracted from soil by wet-sieving and decanting. Transactions of the British Mycological Society 46: 235-244.

Gianinazzi S, Gollotte A, Binet M-N, Tuinen D, Redecker D, Wipf D. 2010. Agroecology: the key role of arbuscular mycorrhizas in ecosystem services. Mycorrhiza. 20: 519-530.

Hammer O, Harper DAT, Ryan PD. 2001. Past: paleontological statistics software package for education and data analysis. Paleontologia Electronica 4: 1-9.

Jackson ML. 1967. Soil chemical analysis. New Delhi, Prentice Hall.

Körner C. 1999. Alpine plant life: functional plant ecology of high mountain ecosystems. Berlin, Springer Berlin Heidelberg. 
Koske RE, Tessier B. 1983. A convenient permanent slide mountaing medium. Mycological Society American News 34: 59.

LiX, Gai J, Cai X, et al. 2014. Molecular diversity of arbuscular mycorrhizal fungi associated with two co-occurring perennial plant species on a Tibetan altitudinal gradient. Mycorrhiza 24: 95-107.

Liu Y, He J, Shi G, An L, Öpik M, Feng H. 2011. Diverse communities of arbuscular mycorrhizal fungi inhabit sites with very high altitude in Tibet Plateau. FEMS Microbiology Ecology 78: 355-365.

Liu L, Hart MM, Zhang J, et al. 2015. Altitudinal distribution patterns of AM fungal assemblages in a Tibetean alpine grassland. FEMS Microbiology Ecology 91:1-11.

Lugo MA, Ferrero M, Menoyo E, Estevez MC, Siñeriz F, Anton A. 2008. Arbuscular Mycorrhizal fungi and rhizospheric bacteria diversity alog an altitudinal gradient in South American Puna grassland. Microbiology Ecology 55: 705-713.

Madigan MT, Martinko JM, Parker J. 2003. Brock biology of microorganisms. 10th. edn. Upper Saddle River, Prentice Hall, Pearson Edition.

Magurran AE. 2004. Measuring biological diversity. Oxford, Blackwell.

Nouhra ER, Urcelay C, Longo MS, Fontenla S. 2011. Differential hypogeous sporocarps production from Nothofagus dombeyi and N. pumilio forests in southern Argentina. Mycologia 104: 45-52.

Oehl F, Schneider D, Sieverding E, Burga CA. 2011a. Succession of arbuscular mycorrhizal communities in the foreland of the retreating Morteratsch glacier in the Central Alps. Pedobiologia 54: 321-331.

Oehl F, Silva GA, Palenzuela J, Sanchez-Castro I, Castillo C, Sieverding C. 2011b. Acaulospora punctata, a new fungal species in the Glomeromycetes from mountainous altitudes of the Swiss Alps and Chilean Andes. Nova Hedwigia 93: 353-362.

Oehl F, Koerner C. 2014. Multiple mycorrhization at the coldest place known for Angiosperm plant life. Alpine Botany 124: 193-198.

Oehl F, Palenzuela J, Sánchez-Castro I, Kuss P, Sieverding E, Silva G. 2012. Acaulospora nivalis, a new fungus in the Glomeromycetes, characteristic for high alpine and nival altitudes of the Swiss Alps. Nova Hedwigia 95: 105-122.

Palenzuela J, Azcon-Aguilar C, Barea JM, Silva GA, Oehl F. 2014. Acaulospora viridis, a new species in the Glomeromycetes from two mountain ranges in Andalucia (Spain). Nova Hedwigia 99: 71-82.

Pereyra HMB, Reyers M, Watanabe E, et al 2005. Condition and trends of ecosystem services and biodiversity. In: Capistrano D, Samper C, Lee MJ, Raudsepp-Hearne C. (eds.) Ecosystems and human well-being: multi scale assessments. Findings of the Sub-global Assessments Working Group of the Millennium Ecosystem Assessment. Washington, Island Press. p. 171-203.
Redecker D, Schüßler A, Stockinger H, Stürmer S, Morton J, Walker C. 2013. An evidence-based consensus for the classification of arbuscular mycorrhizal fungi (Glomeromycota). Mycorrhiza 23: 515-531.

Ricklefs RE, Schluter D. 1993. Species Diversity in Ecological Communities - Historical and Geographical Perspectives. Chicago, The University of Chicago Press.

Schmidt SK, Sobieniak-Wiseman LC, Kageyama SA, Halloy SRP, Schadt CW. 2008. Mycorrhiza and dark-septate fungi in plant roots above 4270 meters elevation in the Andes and Rocky Mountains. Arctic Antarctic Alpine Research 40: 576-583.

Smith SE, Read DJ. 2008. The symbionts forming arbuscular mycorrhizas. In: Smith SE, Read DJ. (eds.). Mycorrhizal Symbiosis. San Diego, Academis Press. p 13-41.

Soriano A, Volkheimer W, Walter H, et al. 1983. Deserts and semideserts of Patagonia. In: West NE. (ed.) Temperate Deserts and Semideserts. Amsterdam, Elsevier Sci Pub Co. p. 423-460.

Turrini A, Giovannetti M. 2012. Arbuscular mycorrhizal fungi in national parks, nature reserves and protected areas worldwide: a strategic perspective for their in situ conservation. Mycorrhiza 22: 81-97.

Urcelay C, Acho J, Joffre R. 2011. Fungal root symbionts and their relationship with fine root proportion in native plants from the Bolivian highlands above 3700 meters elevation. Mycorrhiza 21: 323-330.

Velázquez MS, Cabello M, Irrazabal G, Godeas A. 2008. Acaulosporaceae from El Palmar Nacional Park, Entre Ríos, Argentina. Mycotaxon 103: 171-187.

Velázquez MS, Biganzoli F, Cabello MN. 2010. Arbuscular micorrhizal fungi in El Palmar Nacional Park (Entre Ríos Province, Argentina)- a protected reserve. Sydowia 62: 149-163.

Walker C, Wize CW, McNabb HS. 1982. Population of Endogonaceous fungi at two locations in central Iowa. Canadian Jounal of Botany 60: 2518-2529.

Walkley A, Black IA. 1934. An examination of the Degtjareff method for determining organic carbon in soils: Effect of variations in digestion conditions and of inorganic soil constitutens. Soil Science 63: 251-263.

Wang B, Qiu Y-L. 2006. Phylogenetic distribution and evolution of mycorrhizas in land plants. Mycorrhiza 16: 299-363.

Zhang Y, Gui LD, Liu RJ. 2004. Survey of arbuscular mycorrhizal fungi in deforested and natural forest land in the subtropical region of Dujiangyan, southwest China. Plant Soil 261: 257-263. 